\title{
Clues to the Opioid Crisis in Monitoring the Future but Still Looking for Solutions
}

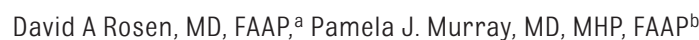

Monitoring the Future, a nationally representative cross-sectional survey of high school students, has collected data from high school seniors for $>40$ years. ${ }^{1}$ In this issue of Pediatrics, McCabe et $\mathrm{al}^{2}$ report findings on changes over time in medical and nonmedical use of prescribed opiates among high school seniors. ${ }^{2}$ This research is important because nonmedical use of prescribed opiates (NUPO) is believed to be a major cause of morbidity and mortality associated with opiates. $^{3}$

The consistency of the Monitoring the Future survey provides a high-level view of opiate use across the country from 1975 to 2015. Although helpful, this perspective can obscure critically important changes in local areas or within specific populations.

As might be expected, the study found that NUPO correlated with opioid prescriptions at yearly evaluations over the 40 years. The study also found that although women received more prescription opiates, the incidence of NUPO did not vary by sex. Overall, white adolescents received more prescription opioids than black adolescents and were more likely to report NUPO. However, it is important to recognize the strong relationship between opioid prescription and NUPO, regardless of race. These findings support the policy recommendations to prescribe opioids only when patients have strong indications for opioids and no better treatment options are available.
McCabe et al found a recent decrease in the medical use of prescription opioids and NUPO. This decrease is consistent with findings from the Centers for Disease Control and Prevention's Youth Risk Behavior Surveillance System from 2009 to $2015 .{ }^{4}$ We view it as an important finding, but there are significant small area variations that would not appear in a national study. The epidemic of opioid use disproportionately affects some urban and more rural areas. NUPO in general has become more common in rural areas. West Virginia, a predominantly rural state, has the highest rate of opioid overdose fatality in the country at 41.5 deaths per 100000 in $2015 .^{3}$ The state also has the second highest rate of opioid prescriptions per capita.

The study by McCabe et al has the same limitations as all large selfreport surveys, including the potential for biased reporting. Additionally, high school seniors with NUPO and other serious and multiple problem behaviors are less likely to be attending school on the survey date or even to be enrolled in 12 th grade. Despite these limitations, these data are valuable. Americans consume 80\% of the world's prescription opioids, and inappropriate use takes a high toll on society. ${ }^{5}$ We are heartened to see a recent decrease, but we see it as a measured improvement. We understand that the appropriate use of opioids to manage pain can be helpful for our patients, but we must continue to search for solutions to the current crisis. Possible interventions include
Departments of ${ }^{a}$ Anesthesia and Pediatrics, and bediatrics/Adolescent Medicine, West Virginia University, Morgantown, West Virginia

Opinions expressed in these commentaries are those of the author and not necessarily those of the American Academy of Pediatrics or its Committees.

DOI: $10.1542 /$ peds.2017-0209

Accepted for publication Jan 24, 2017

Address correspondence to David A. Rosen MD, FAAP, Department of Anesthesia and Pediatrics, 1 Medical Center Dr, P0 Box 8255, Morgantown, WV 26506-8255. E-mail: rosend@wvumedicine.org

PEDIATRICS (ISSN Numbers: Print, 0031-4005; Online, 1098-4275)

Copyright @ 2017 by the American Academy of Pediatrics

FINANCIAL DISCLOSURE: The authors have indicated they have no financial relationships relevant to this article to disclose.

FUNDING: No external funding.

POTENTIAL CONFLICT OF INTEREST: The authors have indicated they have no potential conflicts of interest to disclose

COMPANION PAPER: A companion to this article can be found online at www.pediatrics.org/cgi/doi/ 10.1542/peds.2016-2387

To cite: Rosen DA and Murray PJ. Clues to the Opioid Crisis in Monitoring the Future but Still Looking for Solutions. Pediatrics. 2017;139(4): e20170209 
better education of our patients and families when we prescribe these drugs, better drug regulation, development of new affordable approaches to pain management that have lower potential for abuse, and accessible and affordable treatment programs for those already afflicted.

\section{ABBREVIATION}

NUPO: nonmedical use of prescription opioids

\section{REFERENCES}

1. University of Michigan. Monitoring the Future. Available at: www. monitoringthefuture.org/index.html. Accessed January 19, 2017

2. McCabe S, West B, Veliz P, et al. Trends in medical and nonmedical use of prescription opioids among US adolescents: 1976. Pediatrics. 2016;139(4):e20162387

3. Compton WM, Jones CM, Baldwin GT Relationship between nonmedical prescription-opioid use and heroin use. N Engl J Med. 2016;374(2):154-163
4. National Center for HIV/AIDS, Viral Hepatitis, STD, and TB Prevention, Division of Adolescent and School Health. Trends in the prevalence of marijuana, cocaine, and other illegal drug use. National YRBS: 1991-2015. Available at: https://www.cdc.gov/healthyyouth/data/ yrbs/pdf/trends/2015_us_drug_trend yrbs.pdf. Accessed January 19, 2017

5. American Society of Interventional Pain Physicians. The American Society of Interventional Pain Physicians (ASIPP) fact sheet. Available at: www.asipp.org/ documents/ASIPPFactSheet101111.pdf. Accessed January 19, 2017 